\title{
Corporate Social Responsibility (CSR): A Case Study of Axis Bank Foundation
}

Kavitha $S^{*}$

\section{Abstract}

The article aims to study the importance of CSR and the contribution of our industries towards the betterment and well being of the society. Section 135 of the Companies Act, 2013 has been referred to align industrial CSR activities with considered CSR activities from The Government of India. In the recent years, the banking industry has contributed a lot towards CSR. In this article, the author has taken Axis Bank foundation as a sample to study how exactly CSR activities are undertaken in the corporate, the accountability and reporting of CSR, and the utilisation of funds towards the progress of society. To study CSR activities of Axis Bank, CSR reports have been collected for a period of 3 years (2014-2015 to 2016-2017). The complete study is based on secondary data. The analysis shows that Axis Bank is succeeding in allocating the fund, identifying CSR activities and reporting the same through CSR audited report which is handled by the CSR committee.

Keywords: Corporate social responsivity, Axis bank, Axis bank foundation, Correspondents, Non-government organisation, CSR projects, Companies act 2013

\section{Introduction}

CSR (Corporate Social Responsibility) is one of the vital management concepts whereby firms integrate societal and

* Manipal Academy of Banking, Bengaluru, India;

kavitha.veerendra@gmail.com 
ecological concerns in their business actions for the betterment of the society. Indirectly CSR helps organisations to balance economic, environment, and social obligations aligned with protecting the interest of the stakeholders.

\subsection{Is CSR mandatory for an organisation?}

Though many companies have benefited from society, unfortunately only few business entities have been involved in CSR activities. For the betterment of the society and to encourage a participative approach towards CSR, the government of India introduced the concept of CSR in the new Companies Act 2013, and notified the same under section 135 of the new Companies Act 2013. It has been implemented effectively from 1st of April 2014. Any company or business that has a turnover of more than 1000 crore, net worth of Rs.500 crore and has at least 5 crore of net profit in any financial year must engage in CSR. Also, under the rules, the Government has fixed a threshold limit of $2 \%$ of the "Average" net profits of the block of the previous three years on CSR activities and if the company fails to spend such an amount, disclosures are to be made for the same. But an exemption has been given to the companies that do not satisfy the above threshold for three consecutive years. CSR activities cannot be conducted by firms according to their own preferences. Under Schedule VII of CA 2013, there are certain identified CSR activities. Companies eligible to do CSR should do so under the preview of those activities.

\subsection{Operations of CSR committee}

There is going to be a separate committee which takes care of CSR exclusively in an organisation. The committee will consist of a minimum 3 directors; one being an independent director. The main role of this committee will be the formulation of CSR activities, including the implementation, monitoring and investment on CSR activities. 
Table 1. Overview of CSR contribution from various sectors in the year of 2017 (ngobox.org, 2017)

\begin{tabular}{|c|c|c|c|c|c|c|}
\hline & $\begin{array}{l}\text { Auto and } \\
\text { Auto } \\
\text { Ancillari } \\
\text { es }\end{array}$ & $\begin{array}{c}\text { Banking } \\
\quad \& \\
\text { Finance }\end{array}$ & $\begin{array}{c}\text { Power } \\
\text { Gene ration } \\
\& \\
\text { Distribution }\end{array}$ & $\begin{array}{l}\text { Computers } \\
\text { (Software } \\
\text { and } \\
\text { Hardware) }\end{array}$ & $\begin{array}{c}\text { Metal, } \\
\text { Mineral } \\
\text { and } \\
\text { Mining }\end{array}$ & $\begin{array}{l}\text { Pharma } \\
\text { ceuticals }\end{array}$ \\
\hline $\begin{array}{l}\text { Prescribed } \\
\text { CSR } \\
\text { (Crore) }\end{array}$ & 464 & 1717 & 572 & 1254 & 703 & 383 \\
\hline $\begin{array}{l}\text { Actual } \\
\text { CSR } \\
\text { (Crore) }\end{array}$ & 464 & 1474 & 657 & 1091 & 598 & 314 \\
\hline $\begin{array}{l}\% \text { of } \\
\text { Actual to } \\
\text { Prescribed } \\
\text { CSR }\end{array}$ & $100 \%$ & $86 \%$ & $115 \%$ & $87 \%$ & $85 \%$ & $82 \%$ \\
\hline
\end{tabular}

It can be observed from the above table that the highest prescribed CSR is from the Banking and Finance sector though the actual CSR is $86 \%$. The auto and auto ancillaries sector has spent all prescribed CSR with $100 \%$. An evident performance can be seen from the power generation and the distribution sector by spending more than the prescribed CSR with $115 \%$. Auto and auto ancillaries and power generation and distribution sectors are doing their best to expend according to prescribed norms which in reality leads to the betterment of the society. Having said the above, the other sectors are also putting their effort to spend for CSR according to prescribed norms by spending more than $80 \%$ of prescribed CSR.

\section{CSR activities as prescribed under sub-section 3, section 134 of Companies Act, 2013}

1. Poverty alleviation: eradicating malnutrition and hunger while enhancing better health care.

2. Education: special education and training programmes for women, children and disabled people.

3. Development: developing hostels for women and orphans and taking the initiative for empowering women and lowering inequalities faced by socially and economically backward groups.

4. Ecological balance: environmental sustainability with respect to animal welfare, conservation of natural resources 
and agro-forestry while maintaining the quality of air, water, and soil.

5. Enhancement of craftsmanship: protecting art and culture and taking measures to restore sites of historical importance and national heritage. Also, promoting works of art and setting up of public libraries.

6. Support to armed forces: steps to bring the worthy to the part of war windows, armed force veterans and their departments.

7. Support for sport events: sports programmes and training sessions to enhance the level of rural sports, nationally recognised sports, paralympic sports and olympic sports.

8. Charitable funds: favouring the Prime Minister's National Relief Fund and contributing to other funds set up by the Central Government for promoting socio-economic development and welfare of the schedule castes and schedule tribes as well as for supporting the backward classes.

9. Minorities and women.

10. Technical support: uplifting the technology of the incubator that comes under academic institutions approved by the Central Government.

11. Rural development: introducing varied projects for rural development. 


\section{CSR initiatives of Axis Bank}

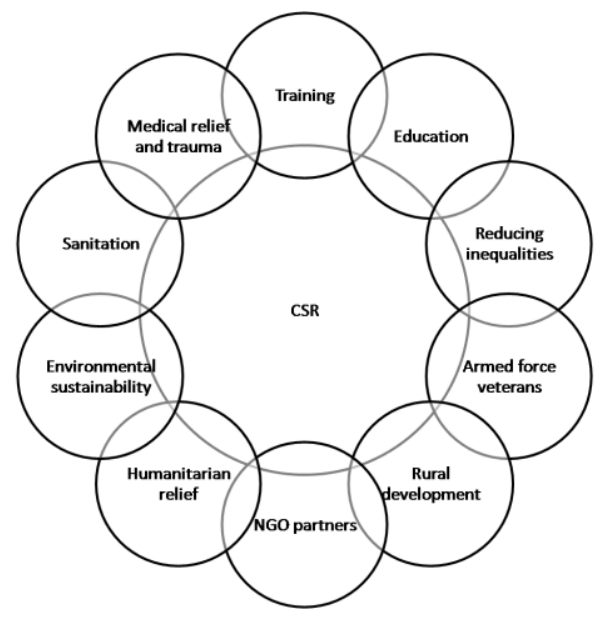

Fig 1 CSR initiatives (Axis Bank CSR Reports)

\subsection{CSR at Axis Bank}

Axis Bank Foundation (ABF) was set up as a public trust in the year 2006 to carry out the CSR initiatives of the bank. The CSR Committee include Shri Som Mittal (Chairman), Shri Rajesh Dahiya and Shri Rajiv Anand as per the financial year 2016-17. ABF has been recognised as the "outstanding Corporate Foundation for the year 2014" by Forbes India.

\subsection{Glimpse of CSR (2014-15)}

The average net profit of the bank for the last three financial years: Rs.6,688.67 Crores. CSR expenditure is $2 \%$ of the profit, that is, 133.77 crores. However, the amount spent was Rs.123.22 crores and the unspent amount is Rs.10.55 crores (Axis Bank Annual Report, 2014-15). 
Table 2: CSR report for the year of 2014-2015 (Axis Bank, 2014-15)

\begin{tabular}{|c|c|c|c|c|c|c|}
\hline $\begin{array}{l}\text { Sl. } \\
\text { No }\end{array}$ & CSR Project & $\begin{array}{l}\text { Sector of } \\
\text { the project }\end{array}$ & $\begin{array}{l}\text { Project } \\
\text { under } \\
\text { taken }\end{array}$ & $\begin{array}{c}\text { Amount } \\
\text { spent } \\
\text { (crores) } \\
(2014-15)\end{array}$ & $\begin{array}{l}\text { Cumulative } \\
\text { expenditure } \\
\text { From } 2006 \\
\text { to } 2014-15\end{array}$ & $\begin{array}{c}\text { Partnering } \\
\text { agencies }\end{array}$ \\
\hline 1 & $\begin{array}{l}\text { Axis bank } \\
\text { Foundation } \\
\text { \& Partner } \\
\text { NGO's }\end{array}$ & $\begin{array}{l}\text { Education } \\
\text { (Primary, } \\
\text { secondary, } \\
\text { supplement } \\
\text { ary } \\
\text { vocational) }\end{array}$ & $\begin{array}{l}\text { Local area } \\
\text { (187 } \\
\text { districts) } \\
\text { Others- } \\
\text { (52district } \\
\text { s) }\end{array}$ & 62.18 & 255.68 & $\mathrm{ABF}$ \\
\hline 2 & $\begin{array}{l}\text { Financial } \\
\text { Literacy \& } \\
\text { inclusion }\end{array}$ & $\begin{array}{l}\text { Education( } \\
\text { Financial } \\
\text { literacy) }\end{array}$ & Local area & 52.32 & 52.32 & $\begin{array}{l}\mathrm{ABF} \text { and } \\
\text { correspond } \\
\text { ents }\end{array}$ \\
\hline 3 & $\begin{array}{l}\text { Environment } \\
\text { al } \\
\text { sustainability }\end{array}$ & $\begin{array}{l}\text { Natural } \\
\text { resource } \\
\text { conservatio } \\
\mathrm{n}\end{array}$ & $\begin{array}{l}\text { Local and } \\
\text { other } \\
\text { areas }\end{array}$ & 5.75 & 5.75 & $\mathrm{ABF}$ \\
\hline 4 & MSME sector & $\begin{array}{l}\text { Education } \\
\text { (Skill } \\
\text { Building) }\end{array}$ & $\begin{array}{l}\text { Local and } \\
\text { other } \\
\text { areas }\end{array}$ & 1.09 & 1.09 & $\mathrm{ABF}$ \\
\hline 5 & $\begin{array}{l}\text { Cleanliness } \\
\text { and } \\
\text { sanitation }\end{array}$ & Sanitation & $\begin{array}{l}\text { Local and } \\
\text { other } \\
\text { areas }\end{array}$ & 0.06 & 0.06 & $\mathrm{ABF}$ \\
\hline 6 & $\begin{array}{l}\text { Administrati } \\
\text { ve } \\
\text { expenses:(im } \\
\text { plementation } \\
\text { partner and } \\
\text { Staff cost of } \\
\text { CSR ) } \\
\text { TOTAL }\end{array}$ & $\begin{array}{l}\text { Allowed } \\
\text { under Rule } \\
4 \text {, sub rule } 6 \\
\text { of CSR } \\
\text { Rules } 2014\end{array}$ & $\begin{array}{l}\text { Not } \\
\text { applicable }\end{array}$ & 123.22 & 316.72 & $\mathrm{ABF}$ \\
\hline
\end{tabular}

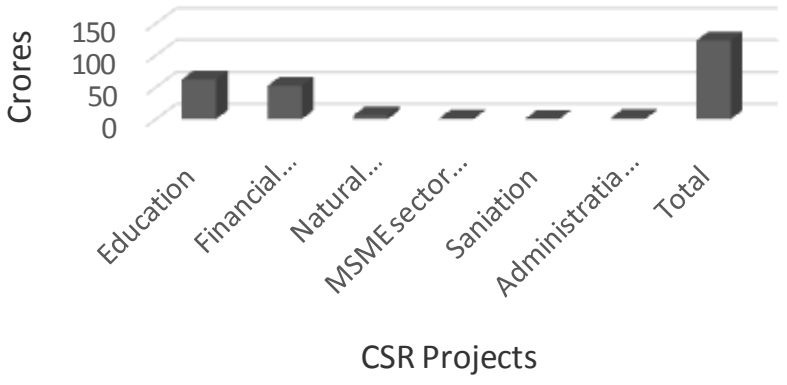

Fig1 Amount Spent on CSR in the year of 2014-15 (Axis Bank, 2015) 


\subsection{Glimpse of CSR (2015-16)}

The average net profit of the bank for last three financial years is Rs.8151.34 Crores.

CSR expenditure is $2 \%$ of the profit is 163.03 crores and the amount spent is Rs.137.41 crores whereas unspent is Rs.25.62 Crores (Axis Bank Annual Report, 2015-16).

Table 3 CSR Report for the year of 2015-2016 (Axis Bank, 2015-16)

\begin{tabular}{|c|c|c|c|c|c|c|}
\hline $\begin{array}{l}\text { Sl. } \\
\text { No }\end{array}$ & CSR Project & $\begin{array}{l}\text { Sector of the } \\
\text { project }\end{array}$ & $\begin{array}{c}\text { Project } \\
\text { underta } \\
\text { ken }\end{array}$ & $\begin{array}{c}\text { Amount } \\
\text { spent } \\
\text { (crores) } \\
(2015-16)\end{array}$ & $\begin{array}{c}\text { Cumulative } \\
\text { expenditure } \\
\text { From } 2006 \\
\text { to 2015-16 }\end{array}$ & $\begin{array}{c}\text { Partnering } \\
\text { agencies }\end{array}$ \\
\hline 1 & $\begin{array}{l}\text { Axis bank } \\
\text { Foundation \& } \\
\text { Partner } \\
\text { NGO's }\end{array}$ & $\begin{array}{l}\text { Education } \\
\text { (Primary, } \\
\text { secondary, } \\
\text { supplementa } \\
\text { ry vocational) }\end{array}$ & $\begin{array}{l}\text { Local } \\
\text { area(213 } \\
\text { districts) } \\
\text { Others- } \\
\text { (28 } \\
\text { districts) }\end{array}$ & 73.58 & $\begin{array}{l}329.26 \text { since } \\
2006-07\end{array}$ & $\begin{array}{l}\text { ABF and } \\
\text { Partner } \\
\text { NGOs }\end{array}$ \\
\hline 2 & $\begin{array}{l}\text { Financial } \\
\text { Literacy \& } \\
\text { inclusion }\end{array}$ & $\begin{array}{l}\text { Education(Fi } \\
\text { nancial } \\
\text { literacy) }\end{array}$ & $\begin{array}{l}\text { Local } \\
\text { area }\end{array}$ & 30.03 & $\begin{array}{l}82.35 \\
\text { (since 2014- } \\
15 \text { ) }\end{array}$ & $\begin{array}{l}\text { ABF and } \\
\text { Business } \\
\text { corresponde } \\
\text { nts }\end{array}$ \\
\hline 3 & $\begin{array}{l}\text { Environmenta } \\
1 \text { sustainability }\end{array}$ & $\begin{array}{l}\text { Natural } \\
\text { resource } \\
\text { conservation }\end{array}$ & $\begin{array}{l}\text { Local } \\
\text { and } \\
\text { other } \\
\text { areas }\end{array}$ & 28.35 & $\begin{array}{l}34.10 \text { (since } \\
2014-15 \text { ) }\end{array}$ & $\mathrm{ABF}$ \\
\hline 4 & MSME sector & $\begin{array}{l}\text { Education } \\
\text { (Skill } \\
\text { Building) }\end{array}$ & $\begin{array}{l}\text { Local } \\
\text { and } \\
\text { other } \\
\text { areas }\end{array}$ & 1.67 & $\begin{array}{l}2.76 \text { (since } \\
2014-15)\end{array}$ & $\mathrm{ABF}$ \\
\hline 5 & $\begin{array}{l}\text { Education and } \\
\text { skill } \\
\text { development }\end{array}$ & Education & $\begin{array}{l}\text { Local } \\
\text { and } \\
\text { other } \\
\text { areas }\end{array}$ & 2.08 & 2.08 & $\mathrm{ABF}$ \\
\hline 6 & $\begin{array}{l}\text { Administrativ } \\
\text { e } \\
\text { expenses:(imp } \\
\text { lementation } \\
\text { partner and } \\
\text { Staff cost of } \\
\text { CSR) } \\
\text { TOTAL }\end{array}$ & $\begin{array}{l}\text { Allowed } \\
\text { under Rule } 4, \\
\text { sub rule } 6 \text { of } \\
\text { CSR Rules } \\
2014\end{array}$ & $\begin{array}{l}\text { Not } \\
\text { applicab } \\
\text { le }\end{array}$ & 1.70 & $\begin{array}{l}3.52 \text { (since } \\
2014-15)\end{array}$ & $\mathrm{ABF}$ \\
\hline
\end{tabular}




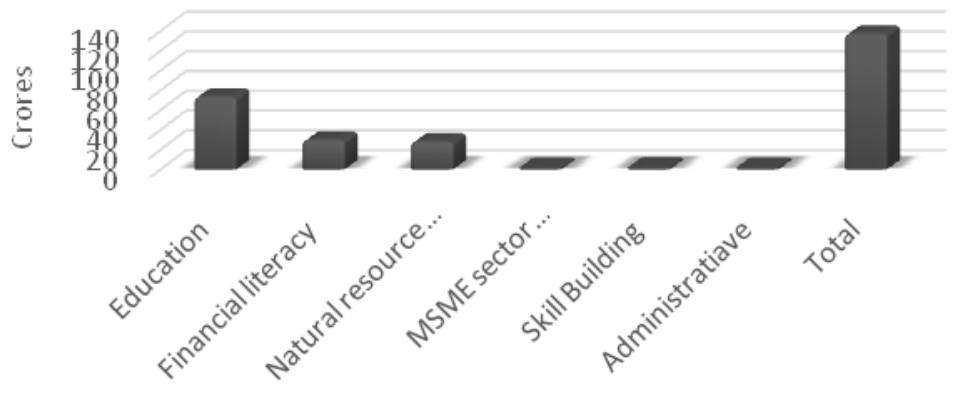

CSR Projects

Fig 2 Amount Spent on CSR in the year of 2015-16 (Axis Bank, 2016)

\subsection{Glimpse of CSR (2016-17)}

The average net profit of the bank for last three financial years: Rs.9821.75 Crores.

The CSR expenditure is $2 \%$ of the profit is 196.44 crores and the amount spent is Rs.135.39 crores and the unspent amount is Rs.61.05 Crores (Axis Bank Annual Report, 2017).

Table 4: CSR report for the year of 2016-2017 (Axis Bank, 2016-17)

\begin{tabular}{|c|c|c|c|c|c|c|}
\hline $\begin{array}{l}\text { Sl. } \\
\text { No }\end{array}$ & $\begin{array}{c}\text { CSR } \\
\text { Project }\end{array}$ & $\begin{array}{c}\text { Sector of the } \\
\text { project }\end{array}$ & $\begin{array}{c}\text { Project } \\
\text { undertak } \\
\text { en }\end{array}$ & $\begin{array}{c}\text { Amount } \\
\text { spent } \\
\text { (crores) } \\
(2016-17)\end{array}$ & $\begin{array}{c}\text { Cumulative } \\
\text { expenditure } \\
\text { From } 2006 \text { to } \\
2016-17\end{array}$ & $\begin{array}{c}\text { Partnering } \\
\text { agencies }\end{array}$ \\
\hline 1 & $\begin{array}{l}\text { Axis bank } \\
\text { Foundation } \\
\text { \& Partner } \\
\text { NGO's }\end{array}$ & $\begin{array}{l}\text { Education } \\
\text { (Primary, } \\
\text { secondary, } \\
\text { supplementa } \\
\text { ry } \\
\text { vocational) }\end{array}$ & $\begin{array}{l}\text { Local } \\
\text { area(211 } \\
\text { districts) } \\
\text { Others- } \\
\text { (10 } \\
\text { districts) }\end{array}$ & 82.24 & $\begin{array}{l}411.50 \text { since } \\
2006-07\end{array}$ & $\begin{array}{l}\text { ABF and } \\
\text { Partner } \\
\text { NGOs }\end{array}$ \\
\hline 2 & $\begin{array}{l}\text { Financial } \\
\text { Literacy \& } \\
\text { inclusion }\end{array}$ & $\begin{array}{l}\text { Education(Fi } \\
\text { nancial } \\
\text { literacy) }\end{array}$ & $\begin{array}{l}\text { Local } \\
\text { area (511 } \\
\text { districts } \\
\text { and } \\
\text { others } 6 \\
\text { districts) }\end{array}$ & 23.30 & $\begin{array}{l}105.65 \\
\text { (since 2014-15) }\end{array}$ & $\begin{array}{l}\text { ABF and } \\
\text { Business } \\
\text { correspon } \\
\text { dents }\end{array}$ \\
\hline 3 & $\begin{array}{l}\text { Environme } \\
\text { ntal } \\
\text { sustainabili } \\
\text { ty }\end{array}$ & $\begin{array}{l}\text { Natural } \\
\text { resource } \\
\text { conservation }\end{array}$ & $\begin{array}{l}\text { Local } \\
\text { and other } \\
\text { areas }\end{array}$ & 18.49 & $\begin{array}{l}52.59 \text { (since } \\
2014-15)\end{array}$ & $\mathrm{ABF}$ \\
\hline 4 & $\begin{array}{l}\text { MSME } \\
\text { sector }\end{array}$ & $\begin{array}{l}\text { Education } \\
\text { (Skill } \\
\text { Building) } \\
\end{array}$ & $\begin{array}{l}\text { Local } \\
\text { and other } \\
\text { areas }\end{array}$ & 3.98 & $\begin{array}{l}\text { 6.74(since 2014- } \\
15 \text { ) }\end{array}$ & $\mathrm{ABF}$ \\
\hline
\end{tabular}


Kavitha S

CSR: A Case Study of Axis Bank Foundation

\begin{tabular}{|c|c|c|c|c|c|c|}
\hline $\begin{array}{l}\text { Sl. } \\
\text { No }\end{array}$ & $\begin{array}{c}\text { CSR } \\
\text { Project }\end{array}$ & $\begin{array}{l}\text { Sector of the } \\
\text { project }\end{array}$ & $\begin{array}{c}\text { Project } \\
\text { undertake } \\
n\end{array}$ & $\begin{array}{l}\text { Amount } \\
\text { spent } \\
\text { (crores) } \\
(2016-17) \\
\end{array}$ & $\begin{array}{c}\text { Cumulative } \\
\text { expenditure From } \\
2006 \text { to } 2016-17\end{array}$ & $\begin{array}{c}\text { Partnering } \\
\text { agencies }\end{array}$ \\
\hline 5 & $\begin{array}{l}\text { Education } \\
\text { and skill } \\
\text { development }\end{array}$ & Education & $\begin{array}{l}\text { Local and } \\
\text { other areas }\end{array}$ & 5.23 & $\begin{array}{l}7.31 \text { (since 2015- } \\
16)\end{array}$ & $\mathrm{ABF}$ \\
\hline 6 & $\begin{array}{l}\text { Administrati } \\
\text { ve } \\
\text { expenses:(im } \\
\text { plementation } \\
\text { partner and } \\
\text { Staff cost of } \\
\text { CSR ) } \\
\text { TOTAL }\end{array}$ & $\begin{array}{l}\text { Allowed under } \\
\text { Rule } 4 \text {, sub } \\
\text { rule } 6 \text { of CSR } \\
\text { Rules } 2014\end{array}$ & $\begin{array}{l}\text { Not } \\
\text { applicable }\end{array}$ & 2.16 & $\begin{array}{l}\text { 5.68(since 2014- } \\
15)\end{array}$ & $\mathrm{ABF}$ \\
\hline
\end{tabular}

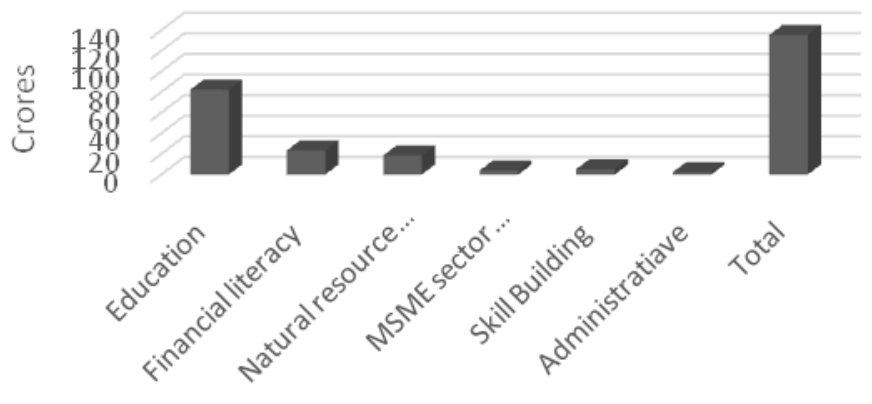

CSR Activities

Fig 3 Amount Spent on CSR in the year of 2016-17 (Axis Bank, 2017)

The average net profit of the bank for last three financial years: Rs.9821.75 Crores. The CSR expenditure is $2 \%$ of the profit, that is, 196.44 crores and the amount spent is Rs.135.39 crores. The unspent amount is Rs.61.05 Crores (Axis Bank Annual Report, 2017).

Table 5 Overview of total expenditure on CSR from 2014 to 2017 (Axis Bank, 2017)

\begin{tabular}{ccccccc}
\hline $\begin{array}{c}\text { Sl. } \\
\text { No }\end{array}$ & Year & $\begin{array}{c}\text { 3 years } \\
\text { average } \\
\text { profit } \\
\text { (Crores) }\end{array}$ & $\begin{array}{c}2 \% \text { of } \\
\text { Average } \\
\text { profit for } \\
\text { CSR } \\
\text { (Crores) }\end{array}$ & $\begin{array}{c}\text { Amount } \\
\text { Spent } \\
\text { (Crores) }\end{array}$ & $\begin{array}{c}\text { Amount } \\
\text { Unspent } \\
\text { (Crores) }\end{array}$ & $\begin{array}{c}\text { \% of } \\
\text { growth } \\
\text { for CSR }\end{array}$ \\
\hline 1 & $2014-15$ & $6,688.67$ & 133.77 & 123.22 & 10.55 & NA \\
2 & $2015-16$ & 8151.34 & 163.03 & 137.41 & 25.62 & 21.87 \\
& & & & & & \\
3 & $2016-17$ & 9821.75 & 196.44 & 135.39 & 61.05 & 20.49 \\
& Total & & 493.24 & 396.02 & 97.22 & \\
\hline
\end{tabular}


The above table explains the average profit of the bank and the contribution towards CSR activities. It can be observed from the above table that each year the company profit has gone up and the CSR amount has also gone up considerably by $21.87 \%$ and $20.49 \%$ respectively between 2014 to 2017.This picture not only elucidates financial growth of the bank but also focusses on the concerns of the bank towards society.

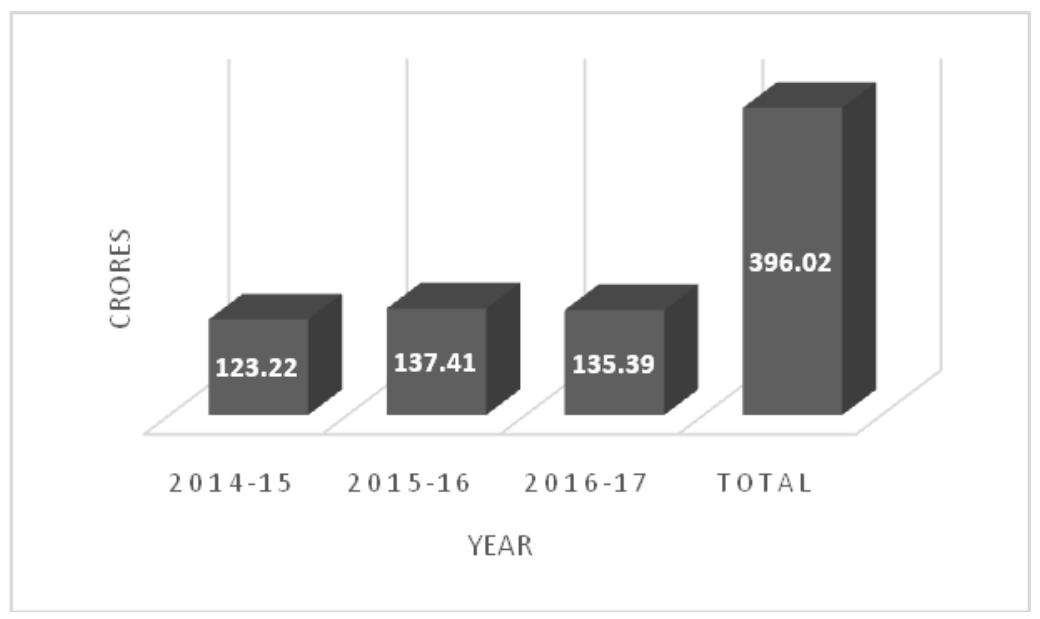

Fig 4 Year-wise Amount Spent on CSR

\section{Conclusion}

Currently, the deportment of CSR in India is directed in a progressive direction. CSR not only helps in bringing up economic viability of the society but also helps an organisation in many ways to earn goodwill in terms of brand visibility, social capital, partnerships, business opportunities, relationships and nation building. Effective CSR can be attained by aligning CSR initiatives to the extent possible with business objectives for better results in the preview of sustainable manner.

The above study depicts that the banking sector in India is showing good interest which is integrated into their business models. In this regard, Axis Bank has put a lot of effort by dedicating one committee to bring forth new ideas and activities through CSR to improve the economic conditions of the society. CEO and Managing Director of Axis Bank, Shikha Sharma, says "The result 
is a positive cycle of company growth and community development, which leads to prosperity that endures" and Axis Bank works on the fundamentals of "Success of the organisation in the long run is depending on wellbeing of the society at the core"(Axis Bank, n.d.). These are the core principles of the bank that really help in society welfare and in the growth of the company too.

\section{References}

Axis Bank. (n.d.). Webpage. Retrieved from https://www.axisbank.com/ Axis Bank. (2015). CSR reports for the year of 2014-15. Retrieved from https://www.axisbank.com/csr

Axis Bank. (2016). CSR reports for the year of 2015-16. Retrieved from https://www.axisbank.com/csr

Axis Bank. (2017). CSR reports for the year of 2016-17. Retrieved from https://www.axisbank.com/csr

Axis Bank. (2015). Annual report-2014-15. Retrieved from https://www.axisbank.com/docs/default-source/annualreports/for-axis-bank/annual-report-2015.pdf?sfvrsn=10

Axis Bank. (2016). Annual report-2015-16. Retrieved from https://www.axisbank.com/docs/default-source/annualreports/for-axis-bank/annual-report-2016.pdf?sfvrsn=10

Axis Bank. (2017). Annual report-2016-17. Retrieved from https://www.axisbank.com/docs/default-source/annualreports/for-axis-bank/annual-report-2015.pdf?sfvrsn=10

Goyal, H., \& Gupta, S. (2013). Corporate Social Responsibility as per New Indian Companies Act 2013, Global Jurix LLP.

ngobox.org. (2017). CSR contribution from various sectors in the year of 2017. Retrieved from http://ngobox.org. 